\title{
Analisis Tingkat Kepuasan Pasien Rawat Inap Rumah Sakit Umum Daerah Bima Provinsi NTB Tahun 2016
}

\author{
Junaidin \\ STIKES Yahya Bima \\ stikyabijunaidin@gmail.com \\ NIDN. 0813128626
}

\begin{abstract}
Abstrak: Rumah sakit merupakan sebuah organisasi yang menjual jasa, maka pelayanan yang berkualitas merupakan hal yang harus dipenuhi sehingga para pemakai jasa mendapatkan kepuasan. Kepuasan pasien di RSUD Bima yang masih rendah menjadi dasar pembenahan di RSUD Bima, salah satunya adalah melalui upaya peningkatan mutu pelayanan. Tujuan penelitian ini adalah menganalisis pengaruh mutu pelayanan kesehatan terhadap kepuasan pasien rawat inap di RSUD Bima Tahun 2016. Penelitian ini dilaksanakan di RSUD Bima Provinsi Nusa Tenggara Barat. Populasi penelitian ini adalah seluruh pasien rawat inap pada bulan Oktober 2016. Sampel dalam penelitian ini sebanyak 100 orang yang dipilih secara acak(Probability Sampling Method) artinya populasi seluruhnya mendapatkan kesempatan yang sama untuk menjadi responden. Teknik analisis data meliputi analisis univariat, analisis bivariat dengan uji Chi Square, dan analisis multivariat dengan menggunakan uji regresi logistik berganda. Hasil penelitian menunjukan dari kelima dimensi mutu pelayanan kesehatan yaitu Reliability,Tangibles, Responsiveness, Assurance,Empathy,semuanya berpengaruh secara signifikan pada kepuasanpasien ( $\mathrm{p}<0,05$ ) dimensiReliabilityyang dilihat adalah pelayanan yang tepat waktu, handal, mandiri dan profesional. Tangibles yang dilihat adalahkebersihan, ketersediaan fasilitas.Responsiveness yang dilihat adalah kecepatan, kemudahan dan kelancaran dari suatu pelayanan. Assurance yang dilihat adalah kemampuan dan keterampilan yang dimiliki oleh tenaga medis dan Empathyyang dilihat adalah sikap dalam menyapa pasien, kurang peduli atas keluhan pasien, sikap berkomunikasi dengan pasien. Disarankan bagi para tenaga medis memperhatikan kebutuhan dan keinginan pasien, serta menumbuhkan kepercayaan dalam hal pelayanan cepat, akurat dan pasti sehingga akan meningkatkan kepuasan pasien.
\end{abstract}

Kata kunci: Dimensi Mutu, Pasien, Kepuasan Pasien.

Palapa: Jurnal Studi Keislaman dan Ilmu Pendidikan Vol 6 No 1 (2018): Mei; p-ISSN 2338-2325; e-ISSN 2540-9697; 


\section{Pendahuluan}

Paradigma baru pelayanan kesehatan mensyaratkan rumah sakit memberikan pelayanan yang berkualitas sesuai kebutuhan dan keinginan pasien dengan tetap mengacu kode etik profesi dan medis. Industri jasa pelayanan kesehatan khususnya rumah sakit beberapa tahun terakhir menunjukkan trend perkembangan. Perkembangan atau pertambahan rumah sakit pemerintah maupun swasta pada setiap daerah di Indonesia membuat peta persaingan industri jasa pelayanan kesehatan yang makin ketat. Hal tersebut mengakibatkan masyarakat semakin kritis dalam memilih pelayanan kesehatan yang berkualitas (Widyaningsih, dkk, 2010).

Pemanfaatan pelayanan rumah sakit pemerintah berdasarkan riset WHO (World Health Organization) lebih tinggi dibandingkan rumah sakit swasta. Perbedaan tingkat pemanfaatan tersebut berpengaruh terhadap tingkat efisiensi rumah sakit seperti; jumlah tempat tidur, jumlah pelayanan rawat jalan, jumlah kunjungan (rawat jalan), jumlah hari rawat (rawat inap), jumlah tindakan operasi, jumlah pemeriksaan laboratorium serta jumlah pemeriksaan radiologi (WHO, 2007).

Dalam konteks kompetisi global di era pasar bebas ini, setiap perusahaan bersaing dengan para pesaing local dan global. Peningkatan intesitas kompetisi menuntut setiap perusahaan untuk selalu memperhatikan dinamika kebutuhan, keinginan dan preferensi konsumen serta berusaha memenuhinya dengan cara-cara yang lebih efektif dan efisien dibadingkan para pesaingnya (Gregorius ,2016).

Terciptanya kepuasan konsumen dapat memberikan beberapa manfaat bagi perusahaan, diantaranya hubungan antara perusahaan dengan konsumen menjadi harmonis, terciptanya loyalitas konsumen serta membentuk rekombinasi dari mulut ke mulut yang menguntungkan perusahaan.

Konsekuensi obyektif dari hal tersebut, perusahaan harus tahu siapa konsumen dan bagaimana tanggapan konsumen terhadap apa yang mereka terima. Hal ini menuntut suatu strategi pemasaran yang efektif untuk lebih memuaskan kebutuhan dan keinginan konsumen. Dalam hal ini perusahaan 
dituntut untuk memantau perilaku konsumen melalui penelitian. Adapun definisi perilaku konsumen adalah sebagai berikut (Swastha dan Handoko, 1982)

Perilaku konsumen tersebut sangat kompleks dan berbeda-beda pada setiap konsumen, keputusan pembelian oleh konsumen dipengaruhi oleh faktor internal dan eksternal. Adapun faktor tersebut adalah :

1. Faktor eksternal meliputi : faktor kebutuhan, kelas sosial, kelompok referensi dan kelompok.

2. Faktor internal meliputi :

a. Faktor pribadi : usia, jabatan, gaya hidup, kepribadian, dan konsep pribadi.

b. Faktor psikologi : motivasi, persepsi, kepercayaan dan sikap.

Dikarenakan perilaku konsumen sangat kompleks dan berbeda-beda pada setiap konsumen. Maka, sebagai salah satu organisasi yang bergerak di bidang jasa pelayanan, rumah sakit juga memerlukan suatu riset konsumen untuk mengetahui persepsi konsumen akan kualitas dari rumah sakit tersebut. Dengan maksud, apakah konsumen telah merasa puas/tidak puas dengan pelayanan yang diberikan oleh pihak rumah sakit. (imbalo S. Pohan 2006).

Standar Pelayanan Minimal Rumah Sakit (SPM) merupakan tolak ukur untuk prestasi kuantitatif dan kualitatif yang digunakan untuk menggambarkan besaran sasaran yang hendak dipenuhi didalam pencapaian suatu SPM tertentu berupa masukan, proses hasil dan manfaat pelayanan. Ada beberapa indicator untuk mengukur kinerja rumah sakit dengan melihat tingkat kesehatan masyarakat antara lain dapat dilihat dari banyaknya orang yang berobat dan menurunnya angka kematian dari ibu yang melahirkan(Kemenkes RI.2008).

Menurut Azwar (2006) kualitas pelayanan kesehatan adalah menunjukkan tingkat kesempurnaan pelayanan kesehatan dalam menimbulkan rasa puas pada diri setiap pasien, makin sempurna kepuasan tersebut, makin baik pula kualitas pelayanan kesehatan di Rumah Sakit. Suatu pelayanan dikatakan baik oleh pasien ditentukan oleh kenyataan apakah jasa yang diberikan bisa memenuhi kebutuhan pasien dengan menggunakan persepsi tentang pelayanan yang diterima. 
Dimensi mutu pokok yang dapat digunakan untuk mengukur persepsi pelanggan tentang mutu pelayanan kesehatan yang meliputi aspek-aspek kualitas pelayanan menurut Parasuraman (dalam Tjiptono, 2007) dibentuk berdasarkan 5 prinsip Service Quality yaitu kecepatan, ketepatan, keramahan dan kenyamanan layanan. Aspek yang dilihat pada kualitas layanan antara lain: Bukti langsung (Tangible), aspek kehandalan (Reliability), daya tanggap (Responsiveness), jaminan (Assurance), dan aspek empati (Empathy).

Salah satu pendekatan kualitas pelayanan yang popular dijadikan acuan dalam riset pemasaran adalah model servqual (Service Quality) yang dikembangkan oleh parasuraman, Zeithaml, dan Berry (1990), SERVQUAL dibangun atas adanya perbandingan dua factor utama, yaitu persepsi pelanggan atas layanan nyata yang mereka terima (perceivend service) dengan layanan sesungguhnya yang diharapkan atau yang diinginkan (expected service). Jika kenyataan lebih dari yang diharapkan, maka layanan tidak bermutu. Apabila kenyataan sama dengan harapan maka layanan tersebut memuaskan.

Pada Pasal 32 UU No.44/2009 tentang Rumah Sakit "Setiap pasien mempunyai hak memperoleh layanan kesehatan yang bermutu sesuai dengan standar profesi dan standar prosedur operasional". Pasien akan merasa puas apabila ada persamaan antara harapan dan kenyataan pelayanan kesehatan yang diperoleh. Kepuasaan pengguna pelayanan kesehatan mempunyai kaitan yang erat dengan hasil pelayanan kesehatan, baik secara medis maupun non medis seperti kepatuhan terhadap pengobatan, pemahaman terhadap informasi medis dan kelangsungan perawatan (Kotler, 1997: 82).

Salah satu rumah sakit pemerintah di Kota dan kabupaten bima yang sudah bekerjasama dengan BPJS adalah Rumah Sakit Umum Daerah (RSUD) Bima. RSUD Bima merupakan rumah sakit Type $C$ yang telah terakreditasi 5 (lima) Pelayanan dasar dengan 155 kapasitas tempat tidur (VIP, Kelas I, II dan III). Secara organisasi rumah sakit ini memberikan pelayanan kesehatan rawat inap, rawat jalan, pelayanan penunjang medis dan pelayanan penunjang non medis serta memiliki fungsi sebagai rumah sakit rujukan dari wilayah sekitarnya.

Survei pendahuluan yang dilakukan pada bulan Febuari 2016, dengan mengobservasi informasi keluhan pasien 13 responden 8 diantara mengatakan 
kurang puas terhadap layanan yang diberikan, Hal itu mencerminkan perlu adanya perbaikan kualitas pelayanan yang diberikan oleh RSUD Bima.

Beberapa hasil penelitian terkait dengan kualitas pelayanan rumah sakit, yaitu hasil penelitian Yuristi Winda, SKM (2013) Menyimpulkan hasil penelitian yang dilakukan di RSUD Lakipadada Kabupaten Tana Toraja tentang hubungan kualitas pelayanan kesehatan dengan kepuasan pasien pengguna askes sosial pada pelayanan rawat inap di RSUD Lakipadada, Ada hubungan antara kualitas pelayanan kesehatan (Reability, Assurance, Tangible, Emphaty, Responsivenses) dengan kepuasan pasien pengguna Askes Sosial pada pelayanan Rawat Inap di RSUD Lakipadada Kabupaten Tana Toraja tahun 2013.

Hotman (2016) dengan judul Pengaruh Kualitas Pelayanan Terhadap Kepuasan Pasien Rawat Inap Peserta Jaminan Kesehatan Nasional (JKN) Kepuasan pasien rawat inap peserta JKN non PBI dalam penelitian ini mengacu kepada kualitas pelayanan yang diterima, yaitu 5(lima) dimensi kualitas pelayanan meliputi: keandalan, ketanggapan, jaminan, empatidan penampilan. Hasil penelitian menunjukkan bahwa tingkat kepuasan pasien rawatinap sebanyak 51,4\% pada kategori tidak puas, selebihnya pada kategori puas dancukup puas. Hal ini berarti pasien rawat inap peserta JKN non PBI belum sepenuhnyapuas dengan pelayanan yang diberikan karena tidak sesuai dengan yang diharapkan pasien.

Mengingat pentingnya mengkaji tentang kepuasan pasien maka perlu dilakukan penelitian tentang Analisis Tingkat Kepuasan Pasien Rawat Inap Rumah Sakit Umum Daerah Bima Provisi Nusa Tenggara Barat 2016

\section{Metode Penelitian}

Penelitian ini menggunakan pendekatan kuantitatif dengan desain Cross Sectional(potong lintang). Rancangan potong lintang dipilih sebagai desain studi dalam penelitian ini karena pengukuran mutu pelayanan (variabel independen) yang berhubungan dengan kepuasan pasien (variabel dependen) dilakukan pada waktu yang sama. 


\section{Hasil dan Pembahasan}

\section{Karakteristik Responden}

Gambaran karakteristik responden di RSUD Bima dapat dilihat pada tabel dibawah ini

Tabel 4.2

Distribusi Frekuensi Jenis Kelamin, Umur, Pendidikan, Pekerjaan, Pendapatan

\begin{tabular}{|c|c|c|c|c|}
\hline \multicolumn{2}{|l|}{ Variabel } & Frekuensi & $(\%)$ & Total \\
\hline \multirow{2}{*}{ Jenis Kelamin } & Laki-Laki & 48 & 48,0 & \multirow{2}{*}{$100 \%$} \\
\hline & Perempuan & 52 & 52,0 & \\
\hline \multirow{2}{*}{ Umur } & $>35$ tahun & 57 & 57,0 & \multirow{2}{*}{$100 \%$} \\
\hline & $<35$ tahun & 43 & 43,0 & \\
\hline \multirow{2}{*}{ Pendidikan } & Tinggi & 46 & 46,0 & \multirow{2}{*}{$100 \%$} \\
\hline & Rendah & 54 & 54,0 & \\
\hline \multirow[b]{2}{*}{ Pekerjaan } & Bekerja & 68 & 17,0 & \multirow[b]{2}{*}{$100 \%$} \\
\hline & $\begin{array}{l}\text { Tidak } \\
\text { bekerja }\end{array}$ & 32 & 83,0 & \\
\hline \multirow{2}{*}{ Pendapatan } & Rendah & 76 & 76,0 & \multirow{2}{*}{$100 \%$} \\
\hline & Tinggi & 24 & 24,0 & \\
\hline
\end{tabular}

Sumber : Data Primer 2016

Berdasarkan Tabel 4.2 dari 100 responden yang diteliti di RSUD Bima pada tahun 2016 terlihat bahwa sebagian besar responden berjenis kelamin Perempuan sebanyak 52,0\%, umur responden lebih banyak yang di atas 35 tahun $57,0 \%$, pendidikan lebih banyak yang renda $54,0 \%$ responden, pekerjaan yang bekerja sebanyak 68,0\% dan pendapatan lebih banyak yang rendah yaitu sebanyak $76,0 \%$.

\section{Analisa Bivariat}

Analisis bivariat digunakan untuk menjelaskan hubungan antar variabel bebas yang menggunakan uji chi-square. Dikatakan ada hubungan 
bermakna secara statistik jika diperoleh nilai $\mathrm{p}<0,05$. Hubungan antar variabel bebas.

dengan variabel terikat dapat dilihat dengan hasil sebagai berikut :

\section{a. Hubungan Karakteristik Responden Dengan Kepuasan Pasien}

\section{Rawat Inap Di Rsud Bima Tahun 2016}

Berdasarkan hasil penelitian menggunakan analisis chi-square didapatkan hasil uji adalah sebagai berikut :

Tabel 4.13.

Hubungan Karakteristik Responden Dengan Kepuasan Pasien Rawat Inap Di Rsud Bima Tahun 2016

\begin{tabular}{|c|c|c|c|c|c|}
\hline \multicolumn{2}{|c|}{ Variabel } & Frekuensi & $(\%)$ & Total & $\mathbf{P}$ \\
\hline \multirow[t]{2}{*}{ Jenis Kelamin } & Laki-Laki & 48 & 48,0 & \multirow[t]{2}{*}{$100 \%$} & \multirow[t]{2}{*}{0.353} \\
\hline & Perempuan & 52 & 52,0 & & \\
\hline \multirow[t]{2}{*}{ Umur } & $>35$ tahun & 57 & 57,0 & \multirow[t]{2}{*}{$100 \%$} & \multirow[t]{2}{*}{0.301} \\
\hline & $<35$ tahun & 43 & 43,0 & & \\
\hline \multirow[t]{2}{*}{ Pendidikan } & Tinggi & 45 & 46,0 & \multirow[t]{2}{*}{$100 \%$} & \multirow[t]{2}{*}{0.000} \\
\hline & Rendah & 54 & 54,0 & & \\
\hline \multirow[t]{2}{*}{ Pekerjaan } & Bekerja & 68 & 68,0 & \multirow[t]{2}{*}{$100 \%$} & \multirow[t]{2}{*}{0.265} \\
\hline & $\begin{array}{l}\text { Tidak } \\
\text { bekerja }\end{array}$ & 32 & 32,0 & & \\
\hline \multirow[t]{2}{*}{ Pendapatan } & Rendah & 76 & 76,0 & \multirow[t]{2}{*}{$100 \%$} & \multirow[t]{2}{*}{0.358} \\
\hline & Tinggi & 24 & 24,0 & & \\
\hline
\end{tabular}

Sumber : Data Primer 2016

Berdasarkan hasil tabulasi Tabel 4.13 dapat dilihat bahwa dari total 100 responden terlihat bahwa sebagian besar responden berjenis kelamin perempuan sebanyak 52,0\%, umur responden lebih banyak yang di atas 
35 tahun 57,0\%, pendidikan lebih banyak yang renda 54,0\% responden, pekerjaan yang bekerja sebanyak 68,0\% dan pendapatan lebih banyak yang rendah yaitu sebanyak $76,0 \%$.

Berdasarkan hasil uji Chi-square maka diperoleh berdasarkan jenis kelamin nilai $\mathrm{p}=0,353$. umur $\mathrm{p}=0,391$. pendidikan $\mathrm{p}=0,000$. pekerjaan $\mathrm{p}=0,265$. pendapatan 0,358 . Hal ini menunjukan bahwa dalam karateristik responden yang memiliki hubungan antara kepuasan adalah pendidikan $\mathrm{p}=0,000$ dengan menunjukan $\alpha<0,05$. Hal ini menunjukan bahwa ada hubungan antara pendidikan dengan kepuasan pasien rawat inap di RSUD Bima.

\section{b. Hubungan Faktor Tangibles Dengan Kepuasan Pasien Rawat Inap di RSUD Bima Tahun 2016}

Berdasarkan hasil penelitian menggunakan analisis Chi-Square didapatkan hasil uji adalah sebagai berikut :

Tabel 4.14.

Tabulasi Silang Faktor Tangibles dengan Kepuasan Pasien Rawat Inap di RSUD Bima Tahun 2016

\begin{tabular}{|c|c|c|c|c|c|c|c|c|c|}
\hline \multirow{3}{*}{$\begin{array}{l}\mathbf{N} \\
\mathbf{o}\end{array}$} & \multirow[t]{3}{*}{ Tamgibles } & \multicolumn{8}{|c|}{ Kepuasan Pasien } \\
\hline & & \multicolumn{2}{|c|}{ Kurang Puas } & \multicolumn{2}{|c|}{ Puas } & \multicolumn{2}{|c|}{ Total } & \multirow{2}{*}{$\mathrm{p}$} & \multirow{2}{*}{$\begin{array}{c}\text { OR } \\
(95 \% \\
)\end{array}$} \\
\hline & & $\mathbf{F}$ & $\%$ & $f$ & $\%$ & $f$ & $\%$ & & \\
\hline 1 & Baik & 18 & 18,0 & 42 & 42,0 & 60 & 60,0 & \multirow[t]{3}{*}{0,001} & \multirow[t]{3}{*}{3.889} \\
\hline 2 & $\begin{array}{l}\text { Kurang } \\
\text { Baik }\end{array}$ & 25 & 25,0 & 15 & 15,0 & 40 & 40,0 & & \\
\hline & Total & 43 & 43,0 & 57 & 57,0 & 100 & 100,0 & & \\
\hline
\end{tabular}

Sumber : Data Primer 2016

Berdasarkan hasil tabulasi silang Tabel 4.14 dapat dilihat bahwa dari total 100 responden, terdapat 40 responden (40,0\%) yang menilai bahwa faktor bukti langsung tergolong kurang baik, sebanyak 25 orang ( $25,0 \%)$ diantaranya merasa kurang puas dengan pelayanan yang diberikan. 
Sedangkan 60 responden $(60,0 \%)$ yang menyatakan bahwa faktor bukti langsung tergolong baik, terdapat 42 responden $(42,0 \%)$ sudah merasa puas dengan pelayanan yang diberikan di RSUD Bima tahun 2016.

Berdasarkan hasil uji Chi-square maka diperoleh nilai $P=0,001$ dengan menunjukan $\alpha<0,05$. Hal ini menunjukan bahwa ada hubungan antara bukti langsung dengan kepuasan pasien rawat inap di RSUD Bima.

\section{c. Hubungan Faktor Reliability dengan Kepuasan Pasien Rawat Inap di RSUD Bima Tahun 2016}

Berdasarkan hasil penelitian menggunakan analisis chi-square didapatkan hasil uji adalah sebagai berikut:

\section{Tabel 4.15 .}

Tabulasi Silang Faktor Reliability dengan Kepuasan Pasien Rawat Inap di RSUD Bima Tahun 2016

\begin{tabular}{|c|c|c|c|c|c|c|c|c|c|}
\hline \multirow[t]{3}{*}{ No } & \multirow[t]{3}{*}{ Reliability } & \multicolumn{7}{|c|}{ Kepuasan Pasien } & \multirow{3}{*}{$\begin{array}{c}\text { OR } \\
(95 \%)\end{array}$} \\
\hline & & \multicolumn{2}{|c|}{$\begin{array}{c}\text { Kurang } \\
\text { Puas }\end{array}$} & \multicolumn{2}{|c|}{ Puas } & \multicolumn{2}{|c|}{ Total } & \multirow[t]{2}{*}{$\mathrm{p}$} & \\
\hline & & $f$ & $\%$ & f & $\%$ & f & $\%$ & & \\
\hline 1 & Baik & 12 & 12,0 & 42 & 42,0 & 54 & 54,0 & \multirow[t]{3}{*}{0,000} & \multirow[t]{3}{*}{5.971} \\
\hline 2 & $\begin{array}{l}\text { Kurang } \\
\text { Baik }\end{array}$ & 29 & 29,0 & 17 & 17,0 & 46 & 46,0 & & \\
\hline & Total & 41 & 41,0 & 59 & 59,0 & 100 & 100,0 & & \\
\hline
\end{tabular}

Sumber : Data Primer 2016

Berdasarkan hasil tabulasi silang Tabel 4.15 dapat dilihat bahwa dari total 100 responden, terdapat 46 responden (46,0\%) yang menilai bahwa faktor kehandalan tergolong kurang baik, sebanyak 29 orang ( $29,0 \%)$ diantaranya merasa kurang puas dengan pelayanan yang diberikan. Sedangkan 54 responden $(54,0 \%)$ yang menyatakan bahwa faktor kehandalan tergolong baik, terdapat 42 responden $(42,0 \%)$ sudah merasa puas dengan pelayanan yang diberikan di RSUD Bima tahun 2016. 
Berdasarkan hasil uji Chi-square maka diperoleh nilai $P=0,000$ dengan menunjukan $\alpha<0,05$. Hal ini menunjukan bahwa ada hubungan antara kehandalan dengan kepuasan pasien rawat inap di RSUD Bima.

\section{d. Hubungan Faktor Responsiveness Dengan Kepuasan Pasien}

\section{Rawat Inap di RSUD Bima Tahun 2016}

Berdasarkan hasil penelitian menggunakan analisis Chi-Square didapatkan hasil uji adalah sebagai berikut:

Tabel 4.16.

Tabulasi Silang Faktor Responsiveness dengan Kepuasan Pasien Rawat Inap di RSUD Bima Tahun 2016

\begin{tabular}{|c|c|c|c|c|c|c|c|c|c|}
\hline \multirow[t]{3}{*}{ No } & \multirow[t]{3}{*}{ Responsiveness } & \multicolumn{7}{|c|}{ Kepuasan Pasien } & \\
\hline & & \multicolumn{2}{|c|}{$\begin{array}{c}\text { Kurang } \\
\text { Puas }\end{array}$} & \multicolumn{2}{|c|}{ Puas } & \multicolumn{2}{|c|}{ Total } & \multirow[t]{2}{*}{$\mathrm{p}$} & \multirow{2}{*}{$\begin{array}{c}\text { OR } \\
(95 \%)\end{array}$} \\
\hline & & f & $\%$ & f & $\%$ & f & $\%$ & & \\
\hline 1 & Baik & 16 & 16,0 & 45 & 45,0 & 61 & 61,0 & \multirow[t]{3}{*}{0,002} & \multirow[t]{3}{*}{3.640} \\
\hline 2 & Kurang Baik & 22 & 22,0 & 17 & 17,0 & 39 & 39,0 & & \\
\hline & Total & 38 & 38,0 & 62 & 62,0 & 100 & 100,0 & & \\
\hline
\end{tabular}

Sumber: Data Primer 2016

Berdasarkan hasil tabulasi silang Tabel 4.16 dapat dilihat bahwa dari total 100 responden, terdapat 39 responden (39,0\%) yang menilai bahwa faktor daya tanggap tergolong kurang baik, sebanyak 22 orang (22,0\%) diantaranya merasa kurang puas dengan pelayanan yang diberikan. Sedangkan 61 responden $(61,0 \%)$ yang menyatakan bahwa faktor daya tanggap tergolong baik, terdapat 45 responden $(45,0 \%)$ sudah merasa puas dengan pelayanan yang diberikan di RSUD Bima tahun 2016.

Berdasarkan hasil uji Chi-square maka diperoleh nilai $P=0,000$ dengan menunjukan $\alpha<0,05$. Hal ini menunjukan bahwa ada hubungan antara daya tanggap dengan kepuasan pasien rawat inap di RSUD Bima. 


\section{e. Hubungan faktor Assurance dengan Kepuasan Pasien Rawat Inap di RSUD Bima Tahun 2016}

Berdasarkan hasil penelitian menggunakan analisis Chi-Square didapatkan hasil uji adalah sebagai berikut:

Tabel 4.17.

Tabulasi Silang Faktor Assurance dengan Kepuasan Pasien Rawat Inap di RSUD Bima Tahun 2016

\begin{tabular}{|c|c|c|c|c|c|c|c|c|c|}
\hline \multirow[t]{3}{*}{ No } & \multirow[t]{3}{*}{ Assurance } & \multicolumn{7}{|c|}{ Kepuasan Pasien } & \multirow{3}{*}{$\begin{array}{c}\text { OR } \\
(95 \%)\end{array}$} \\
\hline & & \multicolumn{2}{|c|}{ Kurang Puas } & \multicolumn{2}{|c|}{ Puas } & \multicolumn{2}{|c|}{ Total } & \multirow[t]{2}{*}{$\mathrm{p}$} & \\
\hline & & f & $\%$ & $f$ & $\%$ & $f$ & $\%$ & & \\
\hline 1 & Baik & 17 & 17,0 & 44 & 44,0 & 61 & 61,0 & \multirow[t]{3}{*}{0,008} & \multirow[t]{3}{*}{3.020} \\
\hline 2 & $\begin{array}{l}\text { Kurang } \\
\text { Baik }\end{array}$ & 21 & 21,0 & 18 & 18,0 & 39 & 39,0 & & \\
\hline & Total & 38 & 38,0 & 62 & 62,0 & 100 & 100,0 & & \\
\hline
\end{tabular}

Sumber: Data Primer 2016

Berdasarkan hasil tabulasi silang Tabel 4.17 dapat dilihat bahwa dari total 100 responden, terdapat 39 responden $(39,0 \%)$ yang menilai bahwa faktor jaminan tergolong kurang baik, sebanyak 21 orang ( $21,0 \%)$ diantaranya merasa kurang puas dengan pelayanan yang diberikan. Sedangkan 61 responden $(61,0 \%)$ yang menyatakan bahwa faktor jaminan tergolong baik, terdapat 44 responden $(44,0 \%)$ sudah merasa puas dengan pelayanan yang diberikan di RSUD Bima tahun 2016.

Berdasarkan hasil uji Chi-square maka diperoleh nilai $P=0,008$ dengan menunjukan $\alpha<0,05$. Hal ini menunjukan bahwa ada hubungan antara jaminan dengan kepuasan pasien rawat inap di RSUD Bima.

\section{f. Hubungan Faktor Empathy dengan Kepuasan Pasien Rawat Inap} di RSUD Bima Tahun 2016

Berdasarkan hasil penelitian menggunakan analisis Chi-square didapatkan hasil uji adalah sebagai berikut: 
Tabel 4.18.

Tabulasi Silang Faktor Empathy dengan Kepuasan Pasien Rawat Inap di RSUD Bima Tahun 2016

\begin{tabular}{|c|c|c|c|c|c|c|c|c|c|}
\hline \multirow{3}{*}{$\begin{array}{l}\mathbf{N} \\
\mathbf{o}\end{array}$} & \multirow[t]{3}{*}{ Empathy } & \multicolumn{7}{|c|}{ Kepuasan Pasien } & \multirow{3}{*}{$\begin{array}{l}\text { OR } \\
(95 \\
\%)\end{array}$} \\
\hline & & \multicolumn{2}{|c|}{$\begin{array}{c}\text { Kurang } \\
\text { Puas }\end{array}$} & \multicolumn{2}{|c|}{ Puas } & \multicolumn{2}{|c|}{ Total } & \multirow[t]{2}{*}{$\mathrm{p}$} & \\
\hline & & f & $\%$ & f & $\%$ & f & $\%$ & & \\
\hline 1 & Baik & 24 & 24,0 & 41 & 41,0 & 65 & 65,0 & \multirow[t]{3}{*}{0,011} & \multirow{3}{*}{$\begin{array}{c}2.89 \\
1\end{array}$} \\
\hline 2 & $\begin{array}{l}\text { Kurang } \\
\text { Baik }\end{array}$ & 22 & 22,0 & 13 & 13,0 & 35 & 35,0 & & \\
\hline & Total & 46 & 46,0 & 54 & 54,0 & 100 & 100,0 & & \\
\hline
\end{tabular}

Sumber: Data Primer 2016

Berdasarkan hasil tabulasi silang Tabel 4.18 dapat dilihat bahwa dari total 100 responden, terdapat 35 responden $(35,0 \%)$ yang menilai bahwa faktor empati tergolong kurang baik, sebanyak 22 orang ( 22,0\%) diantaranya merasa kurang puas dengan pelayanan yang diberikan. Sedangkan 65 responden $(65,0 \%)$ yang menyatakan bahwa faktor empati tergolong baik, terdapat 41 responden $(41,0 \%)$ sudah merasa puas dengan pelayanan yang diberikan di RSUD Bima tahun 2016.

Berdasarkan hasil uji Chi-square maka diperoleh nilai $P=0,011$ dengan menunjukan $\alpha<0,05$. Hal ini menunjukan bahwa ada hubungan antara empati dengan kepuasan pasien rawat inap di RSUD Bima.

\section{Analisa Multivariat}

Model Satu Analisis Multivariat Faktor-faktor yang Mempengaruhi Kepuasan Pasien Rawat Inap di RSUD Bima Tahun 2016

\begin{tabular}{|c|c|c|c|c|c|c|}
\hline \multicolumn{7}{|c|}{ Model 2 } \\
\hline Variabel & B & S.E. & Wald & Sig. & Exp(B) & $\begin{array}{c}\text { 95.0\% C.I.for } \\
\text { EXP(B) }\end{array}$ \\
& & & & & & \\
\hline
\end{tabular}




\begin{tabular}{|l|r|r|r|r|r|r|r|}
\hline & & & & & & Lower & Upper \\
\hline reliability & 1.463 & 0.465 & 9.921 & 0.002 & 4.319 & 1.738 & 10.736 \\
\hline empathy & 1.122 & 0.491 & 5.223 & 0.022 & 3.069 & 1.173 & 8.031 \\
\hline assurance & 1.075 & 0.478 & 5.067 & 0.024 & 2.930 & 1.149 & 7.470 \\
\hline Constant & - & 1.317 & 18.718 & 0.000 & 0.003 & & \\
& 5.696 & & & & & & \\
\hline
\end{tabular}

Hasil analisis: dapat disimpulkan bahwa dari keseluruhan variabel independen yang diduga mempengaruhi kepuasan pasien di RSUD Bima terdapat satu subvariabel Reliability yang paling berpengaruh terhadap kepuasan dengan $\mathrm{p}$ value $0,002<0,05$. Nilai OR terbesar yang diperoleh yaitu 4,319 artinya Setiap pelayanan memerlukan bentuk pelayanan yang handal, artinya dalam memberikan pelayanan, setiap pegawai diharapkan memiliki kemampuan dalam pengetahuan, keahlian, kemandirian, penguasaan dan profesionalisme kerja yang tinggi, karna Reliability mempunyai peluang 4,308 kali yang mempengaruhi kepuasan pasien di RSUD Bima 2016.

\section{Pembahasan}

\section{Analisis Tingkat Kepuasan Pasien Rawat Inap Rumah Sakit Umum} Daerah Bima Provinsi NTB Tahun 2016.

Kepuasan adalah perasaan senang atau kecewa seseorang yang timbul karena membandingkan kinerja yang dipresepsikan produk (hasil) terhadapekspektasi. Apabila kinerja berada di atas harapan konsumen, maka konsumen akan sangat puas dan demikian pula sebaliknya apabila kinerja yang ada berada di bawah harapan konsumen, maka konsumen akan kecewa. Tjiptono (2004) yang menyatakan bahwa kepuasan konsumen merupakan evaluasi purna bila alternatif yang dipilih sekurang-kurangnya sama atau melampaui harapan konsumen, sedangkan ketidakpuasan timbul apabila hasil (Outcome) tidak memenuhi harapan. 
Kepuasan pelanggan menjadi bagian integral dan menyeluruh dari kegiatan jaminan layanan kesehatan. Artinya kepuasan pelanggan menjadi kegiatan yang tidak dapat dipisahkan dari pengukuran mutu pelayanan kesehatan terhadap pelanggan. Konsekuensi dari pola pikir demikian yang adalah dimensi kepuasan pelanggan menjadi salah satu mutu layanan kesehatan yang penting (Pohan, 2007).

Hasil analisis multivariate variabel mutu pelayanan yang terdiri dari faktor : kehandalan, bukti langsung/fisik, daya tanggap, jaminan dan empati terhadap kepuasan pasien dapat dijelaskan sebagai berikut :

\section{a. Pengaruh Faktor Reliability terhadap Kepuasan Pasien Rawat Inap di RSUD Bima Tahun 2016}

Berdasarkan faktor Reliability/kehandalan diperoleh gambaran bahwa sebesar $46,0 \%$ responden menyatakan kehandalan pelayanan di RSUD Bima tahun 2016 tergolong kurang dan sebanyak 54,0\% responden menyatakan kehandalannya tergolong baik. Dari hasil uji regresi diperoleh bahwa dengan tingkat keyakinan 95,0\% dapat disimpulkan bahwa faktor kehandalan memengaruhi kepuasan pasien rawat inap di RSUD Bima tahun $2016(\mathrm{p}=0,000)$.

Keandalan pelayanan rumah sakit merupakan kemampuan rumah sakit memberikan pelayanan sesuai dengan yang dijanjikan. Menurut Zeithmal dan Berry (1988), salah satu dimensi kualitas pelayanan, yaitu dimensi keandalan merupakan dimensi menyangkut kemampuan petugas kesehatan dalam memberikan pelayanan dengan kualitas yang sama setiap waktu dan memberikan pelayanan secara akurat termasuk kecepatan dan ketepatan petugas dalam memberikan pelayanan.

Berdasarkan hasil penelitian dengan pasien rawat inap di RSUD Bima ditemukan 46,0\% responden menyatakan kehandalan pelayanan di RSUD Bima tahun 2016 tergolong kurang sebagian besar pasien mengeluhkan tentang; pelayanan yang tepat waktu, cepat, sikap dan menanamkan kepercayaan. Bentuk-bentuk pelayanan yang cukup handal di RSUD Bima meliputi; perawat memberikan obat-obatan yang ditetapkan dokter sesuai dengan jadwal pemberian, jadwal mengantar 
makanan yang tepat sesuai dengan waktunya, kebersihan dalam ruangan rawat inap berupa petugas membersihkan ruang rawatan setiap pagi. Tapi pada kenyataanya pelayanan yang diberikan belum maksimal sehingga pasien masih ada yang kurang puas.

Berdasarkan hasil uji statistik secara multivariat diperoleh nilai $p<0,05$, hal ini menunjukkan bahwa kualitas pelayanan dimensi keandalan berpengaruh positif dan signifikan terhadap kepuasan pasien rawat inap di RSUD Bima, yang memberikan makna bahwa semakin handal memberikan pelayanan maka pasien semakin puas.

Faktor kehandalan memengaruhi kepuasan pasien rawat inap di RSUD Bima, sejalan dengan penelitian yang dilakukan Hotman SiringoRingo (2016)mengenai mutu pelayanan yang diperoleh bahwa variabel kehandalan nilai positif menunjukan bahwa adanya hubungan searah yang signifikan antara faktor kehandalan (X1) terhadap kepuasan pasien rawat inap (Y). artiya apabila keandalan pelayanan semakin baik kepuasan pasien juga akan semakin baik.

Konsep dan teori yang mendukung dikemukakan oleh Parasuraman (2011) Inti pelayanan kehandalan adalah setiap pegawai memiliki kemampuan yang handal, mengetahui mengenai seluk beluk prosedur kerja, mekanisme kerja, memperbaiki berbagai kekurangan atau penyimpangan yang tidak sesuai dengan prosedur kerja dan mampu menunjukkan, mengarahkan dan memberikan arahan yang benar kepada setiap bentuk pelayanan yang belum dimengerti oleh masyarakat, sehingga memberi dampak positif atas pelayanan tersebut yaitu pegawai memahami, menguasai, handal, mandiri dan profesional atas uraian kerja yang ditekuninya.

Hasil penelitian ini sesuai dengan teori yang dikemukakan oleh Parasuraman, et al. (2004), yang menyatakan bahwa dimensi kualitas pelayanan jasa yang terkait dengan orang, dimensi Reliability (keandalan) relatif lebih penting. Namun hasil penelitiain ini berbeda dengan penelitian Lee, et al., (2000) yang menyatakan bahwa dimensi Responsiveness lebih penting dalam industri yang berbasis orang. 
Strategi penanganan keluhan yang dianggap efisien adalah memberikan kesempatan dan peluang untuk mengubah pelanggan yang tidak puas menjadi puas. Strategi penanganan masalah tersebut antara lain melalui kecepatan tanggapan, sikap empati terhadap pelanggan, kemudahan bagi pelanggan menghubungi institusi dan keterbukaan menerima kritik (Tjiptono, 2000).

Kehandalan yang ditunjukkan sesuai dalam memberikan pelayanan kepada konsumen dan berpengaruh terhadap kepuasan konsumen atas pelayanan yang diterima. Artinya, kehandalan dalam kualitas pelayanan, perlu dipertahankan dan ditingkatkan, sehingga memberikan kepuasan bagi konsumen.

\section{b. Pengaruh Faktor Tangibles terhadap Kepuasan Pasien Rawat Inap di RSUD Bima Tahun 2016}

Berdasarkan faktor Tangibles/bukti langsung diperoleh hasil bahwa sebanyak 40,0\% responden menyatakan kurang baik dan sebanyak 60,0\% menyatakan faktor bukti langsung tergolong baik. Dari hasil uji regresi diperoleh bahwa dengan tingkat keyakinan 95,0\% dapat disimpulkan bahwa faktor bukti langsung memengaruhi kepuasan pasien rawat inap di RSUD Bima tahun $2016(\mathrm{p}=0,001)$.

Pengertian bukti fisik dalam kualitas layanan adalah bentuk aktualisasi nyata secara fisik dapat terlihat atau digunakan oleh pegawai sesuai dengan penggunaan dan pemanfaatannya yang dapat dirasakan membantu pelayanan yang diterima oleh orang yang menginginkan pelayanan, sehingga puas atas pelayanan yang dirasakan, yang sekaligus menunjukkan prestasi kerja atas pemberian pelayanan yang diberikan (Parasuraman, 2001).

Kualitas layanan sangat ditentukan menurut kondisi fisik pelayanan, yang inti pelayanannya yaitu kemampuan dalam menggunakan alat dan perlengkapan kerja yang dapat dilihat secara fisik, mampu menunjukkan kemampuan secara fisik dalam berbagai penguasaan teknologi kerja dan menunjukkan penampilan yang sesuai dengan kecakapan, kewibawaan dan dedikasi kerja. 
Pengaruh pelayanan fisik terhadap kepuasan pasien dilingkungan RSUD Bima terlihat dari upaya peningkatan bukti fisik dimana lingkungan rumah sakit yang masih dalam taham perbaikan dan penambahan kedung baru namun terlihat cukup bersih, pakaian yang dikenakan oleh tenaga kesehatan terlihat yang rapi serta bersih dan adanya penggunaan Hand-scone bagi tenaga medis sebagai upaya sterilisasi alat-alat medis dalam menangani pasien, meskipun hal tersebut belum sepenuhnya dilakukan, karena di beberapa bagian masih terdapat tenaga medis yang tidak memakai Hand-scone. Dan yang terlihat masih perlu perbaikan adalah dalam hal ruang tunggu keluarga pasien dimana dengan lalu lalang keluarga pasien seharusnya diupayakan ruangan pasien agar tetap bersih dan kebersihan toilet tetap terjaga dan mengupayakan Tempat tidur telah siap dipake rapi dan bersih, ketersediaan obat di Rumah Sakit masih kurang sehingga pasien harus membeli obat diluar.

Konsep dan teori yang mendukung dikemukakan oleh Lupiyoadi (2001) yang menyatakan bahwa kualitas pelayanan bukti fisik dari suatu pemasaran jasa, sangat ditentukan bukti fisik berupa penggunaan alat, ketersediaan perlengkapan yang terpenuhi dan kemampuan individu dari aspek pemasaran untuk memberikan suatu kualitas pelayanan yang dapat memuaskan konsumen.

\section{c. Pengaruh Faktor Responsiveness Terhadap Kepuasan Pasien Rawat Inap di RSUD Bima Tahun 2016}

Hasil penelitian secara univariat Responsiveness/daya tanggapterdapat 39 responden $(39,0 \%)$ yang menilai bahwa faktor daya tanggap tergolong kurang baik. Sedangkan 61 responden $(61,0 \%)$ yang menyatakan bahwa faktor daya tanggap tergolong baik. Dari hasil uji regresi diperoleh bahwa dengan tingkat keyakinan 95,0\% dapat disimpulkan bahwa faktor Responsiveness memengaruhi kepuasan pasien rawat inap di RSUD Bima tahun $2016(\mathrm{p}=0,002)$.

Berdasarkan hasil penelitian menunjukkan bahwa masih ada pasien mengeluh tentang ketanggapan dari segi pelayanan seperti; 
ketanggapan dokter, perawat merespon keluhan pasien, menyampaikan hasil pemeriksaan kepada pasien, memberikan informasi tentang penyakit yang diderita pasien, dan menjelaskan pemberian terapi. Kebanyakan para pasien menginginkan penjelasan yang sedetail mungkin dan akurat tentang kondisi mereka dan memberikan solusi yang tepat terhadap penyakit yang diderita. Hal ini perlu mendapat perhatian manajemen rumah sakit, karena pada dimensi ini harapan pasien pada urutan ke 2 dari 5 dimensi yang diukur.

Secara teoritis dimensi ketanggapan menekankan pada sikap penyedia layanan untuk cepat tanggap dalam menghadapi keluhan dan masalah dari pasien, sehingga menimbulkan kepuasan (Bustami, 2011). Menurut asumsi peneliti, pelayanan berupaya tanggap terhadap pasien, namun karena banyaknya pasien yang diperiksa maka petugas kurang merespon keluhan pasien dan waktu untuk menjelaskan informasi menjadi singkat, sehingga kejelasan informasi yang dibutuhkan pasien tidak sesuai dengan yang diharapkan. Hal ini sejalan dengan pendapat Pohan (2006) menyatakan bahwa pelayanan kesehatan bermutu dengan aspek-aspek yang mempengaruhi kepuasan adalah pasien mendapatkan informasi yang jelas dan menyeluruh tentang apa, siapa, kapan, dimana dan bagaimana layanan kesehatan akan atau telah dilaksanakan, informasi perawatan di rumah dan pencegahan .

Manajemen RSUD Bima perlu meningkatkan ketanggapan petugas dalam memberikan pelayanan. Hal ini dapat dilakukan dengan pendekatan secara persuasif, sehingga petugas memahami kewajiban dan tanggungjawabnya dalam memberikan pelayanan pasien rawat inap.

Berdasarkan hasil uji statistik secara multivariat diperoleh nilai $p<0,05$, hal ini menunjukkan bahwa kualitas pelayanan dimensi ketanggapan berpengaruh positif dan signifikan terhadap kepuasan pasien rawat inap di RSUD Bima, yang memberikan makna bahwa semakin tanggap petugas memberikan pelayanan maka pasien semakin puas. 
Faktor daya tanggap memengaruhi kepuasan pasien rawat inap di RSUD Bima sejalan dengan penelitian yang dilakukan oleh Yuristi Winda, SKM (2013) Menyimpulkan hasil penelitian yang dilakukan di RSUD Lakipadada Kabupaten Tana Toraja dimana diperoleh bahwa faktor daya tanggap berpengaruh postif terhadap kepuasan pasien.

Pada prinsipnya, inti dari bentuk pelayanan yang diterapkan dalam suatu instansi atau aktivitas pelayanan kerja yaitu memberikan pelayanan sesuai dengan tingkat ketanggapan atas permasalahan pelayanan yang diberikan. Kurangnya ketanggapan tersebut dari orang yang menerima pelayanan, karena bentuk pelayanan tersebut baru dihadapi pertama kali, sehingga memerlukan banyak informasi mengenai syarat dan prosedur pelayanan yang cepat, mudah dan lancar, sehingga pihak pegawai atau pemberi pelayanan seyogyanya menuntun orang yang dilayani sesuai dengan penjelasan-penjelasan yang mendetail, singkat dan jelas yang tidak menimbulkan berbagai pertanyaan atau hal-hal yang menimbulkan keluh kesah dari orang yang mendapat pelayanan. Apabila hal ini dilakukan dengan baik, berarti pegawai tersebut memiliki kemampuan daya tanggap terhadap pelayanan yang diberikan yang menjadi penyebab terjadinya pelayanan yang optimal sesuai dengan tingkat kecepatan, kemudahan dan kelancaran dari suatu pelayanan yang ditangani oleh pegawai (Parasuraman, 2001).

Pengaruh faktor daya tanggap terhadap kepuasan pasien rawat Inap di RSUD Bima terlihat dari pasien yang ingin cepat dalam memberikan penanganan, berharap kesembuhan dalam waktu yang secepatnya. Namun masih ditemukan kendala pada beberapa hal seperti pertolongan yang terkadang tidak segera diberikan saat pasien membutuhkan dimana tenaga kesehatan kurang sigap. Hal-hal demikian tersebut berdampak kepada ketidakpuasan pasien atas layanan yang diberikan.

Faktor daya tanggap memengaruhi kepuasan pasien rawat inap di RSUD Bima sejalan dengan teori yang dikemukan oleh Parasuraman 
yang mengatakan bahwa daya tanggap memerlukan adanya penjelasan yang bijaksana, mendetail, membina, mengarahkan dan membujuk agar menyikapi segala bentuk-bentuk prosedur dan mekanisme kerja yang berlaku dalam suatu organisasi, sehingga bentuk pelayanan mendapat respon positif (Parasuraman, 2001).

\section{d. Pengaruh Faktor Assurance terhadap Kepuasan Pasien Rawat}

\section{Inap di RSUD Bima Tahun 2016}

Berdasarkan hasil uji regresi diperoleh bahwa dengan tingkat keyakinan 95,0\% dapat disimpulkan bahwa faktor Assurance/jaminan memengaruhi kepuasan pasien rawat inap di RSUD Bima tahun 2016 dilihat dari nilai $\mathrm{p}=0,008$. Berdasarkan hasil penelitian pada faktor jaminan, diperoleh hasil bahwa sebanyak 39,0\% responden menyatakan bahwa faktor jaminan tergolong kurang baik dan sebanyak 61,0\% responden menyatakan bahwa faktor jaminan sudah baik.

Margaretha (2003) suatu organisasi kerja sangat memerlukan adanya kepercayaan yang diyakini sesuai dengan kenyataan bahwa organisasi tersebut mampu memberikan kualitas layanan yang dapat dijamin sesuai dengan:

1) Mampu memberikan kepuasan dalam pelayanan yaitu setiap pegawai akan memberikan pelayanan yang cepat, tepat, mudah, lancar dan berkualitas, dan hal tersebut menjadi bentuk konkrit yang memuaskan orang yang mendapat pelayanan.

2) Mampu menunjukkan komitmen kerja yang tinggi sesuai dengan bentuk-bentuk integritas kerja, etos kerja dan budaya kerja yang sesuai dengan aplikasi dari visi, misi suatu organisasi dalam memberikan pelayanan.

3) Mampu memberikan kepastian atas pelayanan sesuai dengan perilaku yang ditunjukkan, agar orang yang mendapat pelayanan yakin sesuai dengan perilaku yang dilihatnya.

Jaminan terkait pelayanan dalam hal ini meliputi keyakinan pasien akan kemampuan dan keterampilan yang dimiliki oleh tenaga medis, keamanan pasien dan pelayanan yang dirasakan pasien sesuai dengan 
standar pelayanan. Pasien pada umumnya menginginkan kesinambungan pelayanan dengan petugas kesehatan yang sama.

Kepuasan pasien terhadap kualitas layanan dinyatakan oleh sikap terhadap kompetensi pemberi pelaynan dan perubahan yang dirasakan oleh pasien sebagai hasil dari layanan kesehatan yang diterima (Pohan, 2006). Ketidakpuasan responden atas keterampilan tentang penyakit yang dikeluhkan, kesediaan dokter dihubungi via telepon, pemberian terapi dan penjelasan atas efek samping penggunaan obat yang diberikan. Salah satu penyebab ketidak puasan pasien pada dimensi jaminan disebabkan oleh kesibukan dokter dalam memberikan pelayanan kepada pasien lainnya di rumah sakit, sehingga sedikit waktu yang tersedia untuk berkonsultasi dengan dokter.

Konsep dan teori lain yang mendukung dikemukakan oleh Oemi (1995) menyatakan bahwa dasar-dasar dari suatu pelayanan jasa dalam menjalin suatu kemitraan adalah keyakinan yang ditumbuhkan kepada konsumen, sehingga loyalitas yang diberikan sangat memengaruhi tingkat kepuasan konsumen. Konsumen akan meyakini pelayanan yang diberikan apabila aspek kualitas pelayanan keyakinan dipenuhi berupa sikap yang meyakinkan, motivasi yang ditunjukkan, kesesuaian dalam berbagai pelayanan yang diberikan.

Berdasarkan hasil uji statistik secara multivariat diperoleh nilai $p<0,05$, hal ini menunjukkan bahwa kualitas pelayanan dimensi jaminan berpengaruh positif dan signifikan terhadap kepuasan pasien rawat inap di RSUD Bima, hal ini memberikan makna bahwa semakin terjamin pelayanan yang diberikan maka pasien semakin puas. Hasil penelitian ini sesuai dengan teori yang dikemukakan oleh Parasuraman, et al. (2004), yang menyatakan bahwa kualitas pelayanan dimensi assurance (jaminan) berupa adanya jaminan yang mencakup pengetahuan, ketrampilan petugas, keramahan petugas, kemampuan petugas dalam berkomunikasi, sifat dapat dipercaya dan adanya jaminan keamanan berpengaruh terhadap kepuasan pasien. 
e. Pengaruh Faktor Empathiy terhadap Kepuasan Pasien Rawat Inap di RSUD Bima Tahun 2016

Berdasarkan faktor empati diperoleh bahwa sebagian besar responden $(35,0 \%)$ menyatakan bahwa pelayanan Empathiy/empati tenaga kesehatan RSUD Bima kurang baik dan sebagian besar (65,0\%) menyatakan pelayanan empati tergolong baik. Dari hasil uji regresi diperoleh bahwa dengan tingkat keyakinan 95,0\% dapat disimpulkan bahwa faktor empati mempengaruhi kepuasan pasien rawat inap di RSUD Bima tahun $2016(\mathrm{p}=0,011)$.

Hal ini memberikan gambaran bahwa pelayanan berdasarkan empati pelayanan yang diberikan oleh RSUD Bima sudah berupaya untuk mendapatkan perhatian pasien untuk perduli, sabar, dan memotivasi pasien dalam memberikan pelayanan walaupun belum sepenuhnya sesuai dengan harapan pasien. Sedangkan bagi pasien yang tidak puas mereka memiliki persepsi bahwa pemberi pelayanan di RSUD Bima belum mampu berinteraksi dengan pasien, sehingga pasien merasa pelayanan yang diberikan tidak puas.

Berdasarkan hasil hasil penelitian masih ada pasien mengeluh tentang perhatian dokter, perawat dan petugas kesehatan lainnya atas pelayanan meliputi; sikap dalam menyapa pasien, kurang peduli atas keluhan pasien, sikap berkomunikasi dengan pasien, sikap dalam menjelasakan proses terapi dan sikap dalam memotivasi pasien untuk sembuh. Hal ini juga perlu mendapat perhatian manajemen rumah sakit, walaupun pada dimensi ini harapan pasien pada urutan ke 5 atau paling rendah. Manajemen RSUD Bima harus berupaya meningkatkan dimensi perhatian dalam rangka meningkatkan kepuasan pasien.

Kebutuhan empati yang belum dipenuhi, berdampak kepada responden untuk ingin memilih sarana pelayanan kesehatan lain jika dimungkinkan. Hubungan antar manusia dalam layanan kesehatan merupakan interaksi antara petugas kesehatan dengan pasien, secara psikologis perhatian pemberi pelayanan dalam mendengarkan keluhan 
serta memberi kesempatan pasien untuk bertanya maka pasien akan merasa dihargai.

Berdasarkan hasil uji statistik secara multivariat diperoleh nilai $p<0,05$, hal ini menunjukkan bahwa kualitas pelayanan dimensi empati berpengaruh positif dan signifikan terhadap kepuasan pasien rawat inap di RSUD Bima

Hasil penelitian ini sesuai dengan teori yang dikemukakan oleh Parasuraman, et all. (2004), yang menyatakan bahwa kualitas pelayanan dimensi empati adalah kualitas pelayanan berupa pemberian perhatian yang sungguh-sungguh dari pemberi pelayanan kepada konsumen secara individual.

Faktor empati memengaruhi kepuasan pasien rawat inap di RSUD Bima sejalan dengan penelitian yang dilakukan oleh Gary Leonard Hendrik, dengan judul Analisis Pengaruh Kualitas Layanan Terhadap Kepuasan Pasien Pada RS Elim Kab. Toraja Utara. Hasil analisis penelitian ini dengan menggunakan SPSS 16,0 menunjukkan bahwa variabel Emphaty berpengaruh terhadap kepuasan pasien.

Empati dalam suatu pelayanan adalah adanya suatu perhatian, keseriusan, simpatik, pengertian dan keterlibatan pihak-pihak yang berkepentingan dengan pelayanan untuk mengembangkan dan melakukan aktivitas pelayanan sesuai dengan tingkat pengertian dan pemahaman dari masing-masing pihak tersebut. Pihak yang memberi pelayanan harus memiliki empati memahami masalah dari pihak yang ingin dilayani. Pihak yang dilayani seyogyanya memahami keterbatasan dan kemampuan orang yang melayani, sehingga keterpaduan antara pihak yang melayani dan mendapat pelayanan memiliki perasaan yang sama.

Menurut Margareth (2003) bentuk kualitas layanan dari empati orang-orang pemberi pelayanan terhadap yang mendapatkan pelayanan harus diwujudkan dalam lima hal yaitu: 
1) Mampu memberikan perhatian terhadap berbagai bentuk pelayanan yang diberikan, sehingga yang dilayani merasa menjadi orang yang penting.

2) Mampu memberikan keseriusan atas aktivitas kerja pelayanan yang diberikan, sehingga yang dilayani mempunyai kesan bahwa pemberi pelayanan menyikapi pelayanan yang diinginkan.

3) Mampu menunjukan rasa simpatik atas pelayanan yang diberikan, sehingga yang dilayani merasa memiliki wibawa atas pelayanan yang dilakukan.

4) Mampu menunjukkan pengertian yang mendalam atas berbagai hal yang diungkapkan, sehingga yang dilayani menjadi lega dalam menghadapi bentuk-bentuk pelayanan yang dirasakan.

5) Mampu menunjukkan keterlibatannya dalam memberikan pelayanan atas berbagai hal yang dilakukan, sehingga yang dilayani menjadi tertolong menghadapi berbagai bentuk kesulitan pelayanan.

\section{Kesimpulan}

Setelah dilakukan penelitian tentang analisis tingkat kepuasan pasien rawat inap di RSUD Bima provinsi NTB tahun 2016, maka dapat disimpulkan bahwa kepuasan pasien RSUD Bima kurang puas terhadap pelayanan yang didapatkan. Hal ini disebabkan karena adanya hubungan dan pengaruh dari beberapa faktor, antara lain :

1. Pelayanan kesehatan berdasarkan Reliability berpengaruh terhadap kepuasan pasien artinya Pelayanan kesehatan berdasarkan Reliabilityyang kurang baik berpeluang 6 kali mengakibatkan ketidak puasan pasien rawat inap di RSUD Bima tahun 2016.

2. Pelayanan kesehatan berdasarkan Tangiblesberpengaruh terhadap kepuasan pasien artinya Pelayanan kesehatan berdasarkan Tangiblesyang kurang baik berpeluang 4 kali mengakibatkan ketidak puasan pasien rawat inap di RSUD Bima tahun 2016. 
3. Pelayanan kesehatan berdasarkan Responsivenessberpengaruh terhadap kepuasan pasien artinya Pelayanan kesehatan berdasarkan Responsiveness yang kurang baik berpeluang 3 kali mengakibatkan ketidak puasan pasien rawat inap di RSUD Bima tahun 2016.

4. Pelayanan kesehatan berdasarkan Assurance berpengaruh terhadap kepuasan pasien artinya Pelayanan kesehatan berdasarkan Assurance yang kurang baik berpeluang 3 kali mengakibatkan ketidak puasan pasien rawat inap di RSUD Bima tahun 2016.

5. Pelayanan kesehatan berdasarkan Empathy berpengaruh terhadap kepuasan pasien artinya Pelayanan kesehatan berdasarkan Empathy yang kurang baik berpeluang 2 kali mengakibatkan ketidak puasan pasien rawat inap di RSUD Bima tahun 2016.

6. Berdasarkan hasil penelitian ditemukan bahwa dimensi kualitas pelayanan berdasarkan Reliability yang dominan berpengaruh terhadap kepuasan.

7. Karakteristik Responden dari lima penilaian jenis kelamin, umur, pendidikan, pekerjaan pendapatan. Hanya satu yang berhubungan dengan kepuasan pasien yaitu pendidikan Berdasarkan hasil uji Chi-square $\mathrm{p}=0,000$. semakin tinggi tingkat pendidikan seseorang semakin besar pula keinginan dan harapannya, maka tingkat pendidikan yang tinggi akan cenderung menyebabkan tingkat kepuasan yang rendah sehingga diperlukan pelayanan yang berkualitas tinggi untuk mendapatkan kepuasan. 


\section{DAFTAR PUSTAKA}

Tjiptono, Fandy \& Chandra, Gregorius. 2016. Buku Servise, Quality dan Satisfaction, edisi 4. hal.120. Yogyakarta.

Parasuraman, Zeithaml Berry. 2014. Metode Analisis Kualitas Pelayanan dalam Journal of Retailing, Volume 64 Number 1.

Winda, Y. 2013. Hubungan Kualitas Pelayanan Kesehatan Dengan Kepuasan Pasien Pengguna Askes Sosial Pada Pelayanan Rawat Inap Di RSUD Lakipadada Kabupaten Tana Toraja Tahun 2013. Tana Toraja.

Zeithaml, V.A. Parasuraman \&A. Berny L.L. 1990. Delivering Quality Service: Balancing Customer Perception and Expectations. New York: The Free Press.

Parasuraman, A. Valerie. 2001. Delivering Quality Service. New York: The Free Press.

Margaretha. 2003. Kualitas Pelayanan: Teori dan Aplikasi. Jakarta: Penerbit Mandar Maju.

Candra, P.Syah. 2016. Manajemen keper\#awatan. jakarta: PT IN Media Anjaryani Wiken.

Diah. 2009. Kepuasan Pasien Rawat Inap Terbadap Pelayanan Perawatan di RSUD Tugurejo Semarang.TESIS.

Rico, Jakobus. 2012. Model Kualitas Pelayanan (SERVQUAL) Parasuraman et al.

RSUD Bima. 2015. Profil Rumah Sakit Umum Daerah Bima 2015. Bima.

Yohana, A. 2009. Analisis Kepuasan Pasien Rawat Inap Terbadap Mutu Layanan Rumah Sakit Sunan Kudus. Semarang: Fakultas Ilmu Kesehatan Masyarakat, Universitas Dipoonegoro.

Nova, Fitra R. 2010. Pengarub Kualit Pelayanan Tehadap Kepuasan Pasien Rawat Inap Rumah Sakit Muhammadiya. Surakarta: Fakultas Ekonomi, Universitas Sebelas Maret Surakarta.

Nandaa, An. 2014. Hubungan Kualitas Pelayanan Kesehatan Dengan Tingkat Kepuasan Pasien Di Bp.Gigi Puskesmas Kelayan Dalam Kota Banjarmasin Vol 1 No.1, hal 26.

Khairani, Laila. 2011. Faktor Faktor Yang Mempengarubi Kepuasan Pasien Rawat Jalan RSUD Pasaman Barat. Hal 8.

Imbalo, S. Pohan. 2012. Jaminan Mutu Layanan Kesehatan. Jakarta: penerbit buku kedokteran. 
Nasution, M. N. 2005. Manajemen Mutu Terpadu: Total Quality Management. Bogor: Ghalia.

Bennett, Ruth V. 2002.Myles Textbook for Midwive, Thirteenth Edition. London: Churchill Livingstone.

Utama, S. 2003. Memahami Fenomena Kepuasan Pasien Rumah Sakit.Medan: Fakultas Kesehatan Masyarakat, Universitas Sumatera Utara.

Tjiptono, Fandy \& Chandra, Gregorius. 2016. Buku Servise, Quality dan Satisfaction, Edisi 4. Yogyakarta: andi yogyakarta.

Kotler. 2005. Manajemen Pemasaran, Edisi 11 Jilid 2. Jakarta: Indeks.

Menkes RI. 2004. Keputusan Menteri Kesehatan Republik Indonesia Nomor 1204/MENKES/SK/X/2004 tentang Persyaratan Kesehatan Lingkungan Rumah Sakit. Jakarta: Ditjen PPM \& PLP, Depkes RI.

Menkes RI.2008.Keputusan Menteri Kesehatan RI Nomor 129/MENKES/SK/II/2008 tentang Standar Pelayanan Minimal Rumah Sakit. Jakarta: Depkes RI.

Peraturan Menteri Kesehatan Republik Indonesia Nomor 147. 2010. Tentang Perizinan Rumah Sakit.

Departemen Kesehatan RI. 2009. Undang-Undang Republik Indonesia Nomor 44 Tahun 2009 tentang Rumah Sakit. Jakarta.

Nursalam, Pariani. 2001. Pendekatan Praktis Metodologi Riset Keperawatan. Jakarta: Sagung Seto.

Muninjaya, A.A.Gde. 2004. Manajemen Kesehatan. Buku Kedokteran EGC Edisi kedua. Jakarta.

PPNI. 2002. Pedoman Umum Penyelengaraan Pendidikan Berkelanjutan Bagi Perawat. Jakarta: PPNI.

Lupiyoadi, Hamdani A. 2008. Manajemen Pemasaran Jasa, Edisi Kedua, Cetakan Keempat. Jakarta: Salemba Empat.

\section{Internet Resources}

http://pasca.unand.ac.id/id/wp-content/uploads/2011/09/JURNAL-TESIS-

LAILA.pdf

http://www.depkes.go.id/UU No. 44 Th 2009 tentang_Rumah Sakit. Pdf 